\title{
Preliminary geology, mineral chemistry and diamond results from the C29/30 Candle Lake volcanic complex, Saskatchewan, Canada
}

\author{
D. Verigeanu ${ }^{1}$, C.M. Hetman ${ }^{2}$, B. Jellicoe ${ }^{1}$ and M.C. Baumgartner ${ }^{2}$ \\ ${ }^{1}$ Vaaldiam Resources Ltd., Saskatoon, SK, Canada \\ ${ }^{2}$ Mineral Services Canada Inc., North Vancouver, BC, Canada
}

\section{Introduction}

The C29/30 kimberlite is one of the two diamondiferous bodies that comprise the Candle Lake kimberlite cluster located $\sim 70 \mathrm{~km}$ north of the Fort a la Corne kimberlite field (Fig. 1). C29/30 was discovered in 1994 by War Eagle Mining and Great Western Gold following the discovery of Fort á la Corne. The body has recently been subject to extensive exploration and evaluation by Great Western Diamonds, including airborne and ground magnetic surveys, core drilling and mini-bulk sampling. Investigation and analysis of the drill cores has included detailed core logging and petrography as well as indicator mineral abundance and composition studies. In addition, a significant amount of kimberlite has been treated for micro-diamonds. Macro-diamonds have been recovered from the most recent mini-bulk sample collected from several RC drill holes. This contribution presents an updated geological model based on data obtained from drilling programmes completed in 2006, 2007 and 2008. The morphology and internal geology of the body are used to explain the type and sequence of events involved in its formation.

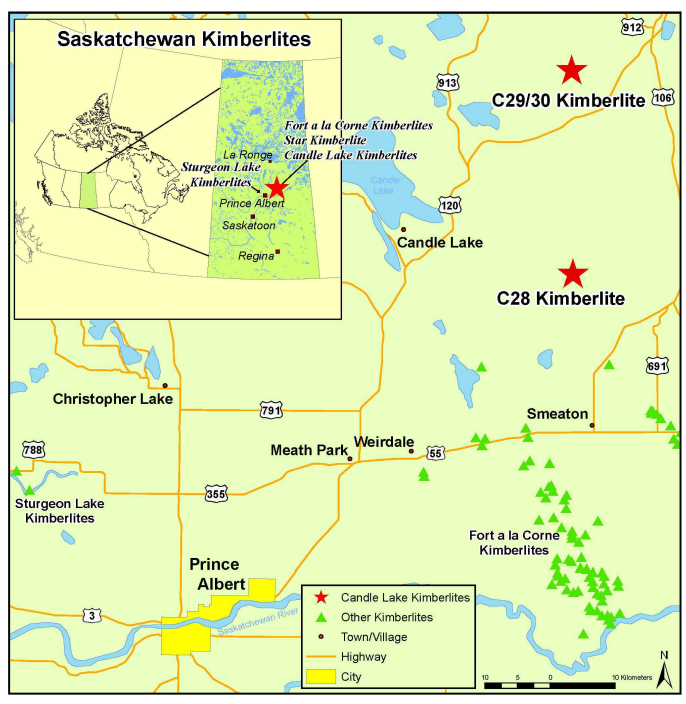

Figure 1: Location of C29/30 and C28 Candle Lake Kimberlites

\section{Geological Setting}

The Candle Lake kimberlites are hosted within a Cretaceous sedimentary sequence consisting of poorly consolidated marine mudstones and shales of the
Lower Colorado Group overlying silts and sands of the Mannville Group. This sequence overlies Paleozoic carbonates that were deposited over Proterozoic granitoids of the Sask Craton (Jellicoe et al., 1998). The Quaternary glacial sediments covering the kimberlites range in thickness from 145 to $165 \mathrm{~m}$. C29/30 is inferred to be Cretaceous in age based on the country rock stratigraphy and morphology of the pipe.

\section{Geology of C29/30}

Investigation of new and historical drill holes and inversion of the magnetic data (Napier, 2008) indicates that $\mathrm{C} 29 / 30$ is one continuous body with a surface expression of approximately 70 ha (Fig. 2). The body has a complex shape that can be divided into three main zones: 1) south circular palaeolow (SP), 2) trough, and 3) north circular palaeolow (NP). The geophysical data over the pipe suggest that the feeder vent is located in the SP; however, this has yet to be confirmed by drilling. The majority of the kimberlite filling of the body is volcaniclastic and characterised by uniform juvenile clast mineralogy and indicator minerals, consistent with derivation from a single phase of kimberlite.

The SP is dominated by volcaniclastic kimberlite (VK) ranging in character from fine-grained, well sorted, thinly bedded deposits to thick, massive, and poorly sorted units. The majority of kimberlite units contain low proportions of country rock xenoliths that include dark brown shaley mudstone as well limestone and basement xenoliths.

Three main units have been identified in the SP, each of which is characterised by distinctive macroscopic features but relatively similar juvenile constituents and mantle-derived indicator minerals. The thin basal unit consists of massive, medium-grained, clast supported and poorly sorted VK with common limestone xenoliths. Juvenile clasts are typically round and rarely amoeboid in shape with a primary mineral assemblage that includes conspicuous altered phlogopite phenocrysts, monticellite, spinel and perovskite. Many of the juvenile clasts are vesicular. The overlying thick sequence of massive to diffusely bedded, medium to coarse-grained, clast to matrix supported and poorly sorted VK is characterized by an increase in country rock xenolith abundance with increasing depth (up to 3-5\% limestone). Juvenile clasts are common and 

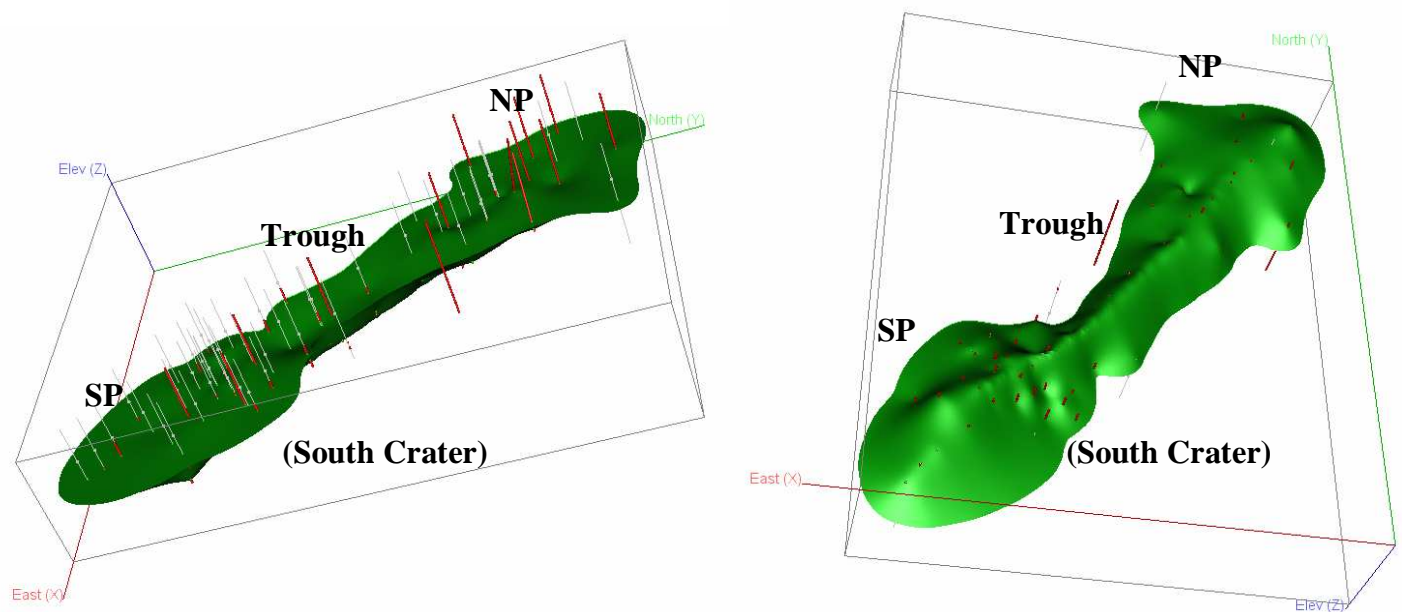

Figure 2: 3D geological model of the C29/30 kimberlite viewed from (a) above and (b) below.

include phlogopite-free and rare phlogopite-bearing types that have more abundant (and coarser) olivine phenocrysts than the juvenile clasts in the basal unit. The uppermost unit in the SP consists of multiple fining-upward beds of fine to medium-grained, clast supported and well sorted VK dominated by olivine crystals and less common juvenile clasts.

In contrast, the NP is infilled by a distinctive mud-rich, juvenile poor VK deposit and large $(10-50 \mathrm{~cm})$ mud and shale clasts similar to those derived from the Lower Colorado Group. The total abundance of kimberlitic constituents in the bulk of the NP infill is visually estimated to be less than $10 \%$, but this gradually increases with depth such that the kimberlite at the base is comprised of abundant juvenile material with a mud-free matrix. This basal unit can be divided into two subunits on the basis of contrasting populations of country rock xenoliths. Most of the VK is dominated by limestone clasts with the second subunit being characterized by abundant basement clasts.

The trough between the two circular palaeolows is infilled with an upper thinly bedded, fine-grained, well sorted VK unit and an underlying massive, mediumgrained and poorly sorted VK zone containing common limestone and basement xenoliths. Mud-rich VK is present but not abundant as is the case in the NP.

\section{Mineral Chemistry}

The indicator mineral suite in the main phase of kimberlite filling the $\mathrm{SP}$ is dominated by high-Cr peridotitic garnet, with lesser chromite and low-Cr eclogitic/megacrystic/pyroxenitic garnet, and trace amounts of mantle-derived ilmenite. The Cr-bearing garnets are dominated by G9 (lherzolitic) and G11 (sheared lherzolitic) compositions which range in $\mathrm{Cr}_{2} \mathrm{O}_{3}$ content from approximately 2 to $12 \mathrm{wt} \%$ (Fig. 3). Sub-calcic G10 (harzburgitic) garnets are rare, have low $\mathrm{Cr}_{2} \mathrm{O}_{3}$ contents, and are only marginally sub- calcic. The absence of G10 garnets derived from the diamond stability field indicates that the C29/30 kimberlite represented by the material analysed has not sampled diamonds of harzburgitic origin. Two populations of low-Cr garnets were identified based on their $\mathrm{Na}_{2} \mathrm{O}-\mathrm{TiO}_{2}$ compositions and some of these have $\mathrm{Na}$ contents $=0.07 \mathrm{wt} \%$. These are interpreted to be derived from high-pressure diamond associated group I eclogitic mantle. Chromite occurs as a low-abundance indicator mineral in the sample processed and only one of the grains analysed has a diamond inclusion type composition (Fig. 3). The mineral composition data from samples of C29/30 processed and evaluated for this study suggest that diamond-bearing lithospheric mantle was sampled by the kimberlite during emplacement, which is consistent with the recovery of diamonds.
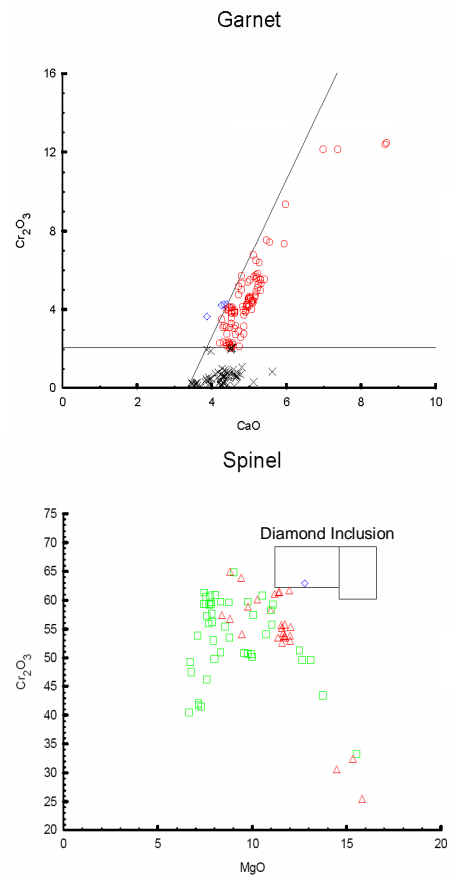

Figure 3: C29/30 garnet and chromite compositions 
The indicator mineral abundance and compositional data further indicate that the primary diamondiferous mantle rock type sampled was eclogite, with a possible small contribution from garnet and chromite peridotite.

\section{Diamond Results}

Total counts for the individual drill holes sampled for micro-diamonds in 2006-2007 vary from 155 to 981 stones/tonne with many of the higher values being reported from SP. Some of the micro-diamonds recovered fell into the larger size classes $(>0.425)$. A total of 370 macro-diamonds (stones $>0.5 \mathrm{~mm}$ in at least two dimensions) with cumulative weight of 14 carats were recovered from a mini-bulk sample collected in 2006-2007. Macro-diamond individual sample grades vary from 0 to $24 \mathrm{cpht}$ and average sample grades per individual drill hole range from 0.7 to $4.6 \mathrm{cpht}$. The basal, massive VKs have total average grades varying from $4.1 \mathrm{cpht}$ in the SP to $3.2 \mathrm{cpht}$ in the NP whereas the total averages of the finer-grained units vary from $1.0 \mathrm{cpht}$ in SP to $1.8 \mathrm{cpht}$ in the trough. Most of the stones are colorless and dominantly distorted or fragments but dodecahedrons, octahedrons and white, amber, yellow, grey or black stones have been reported. The largest stone recovered from the minibulk sample weighs 0.9 carats. Both micro-diamond stone counts and macro-diamond grades commonly vary with depth without an obvious pattern.

\section{Discussion}

The preserved host rock geology overlying the C29/30 body is composed primarily of marine shales and this same material can be found as lithic clasts throughout most of the kimberlite units. The country rock setting combined with the absence of features typically encountered with air fall deposits (bomb sags, ballistic impact fragmentation of lithic clasts etc.) is consistent with emplacement within a marine environment. The country rock surrounding the pipe has not been investigated in detail, so the depth of water present at the time of emplacement is unknown.

The SP is interpreted to have formed by an explosive volcanic process which excavated a roughly circular crater (South Crater) and created a $750 \mathrm{~m}$ long trench ending in a second, shallower NP. The trench and the NP are interpreted to have formed by an erosive process related to the movement of material away from the vent located in the South Crater. The majority of the coarsest kimberlite is located in the South Crater and forms a cone shaped feature within this zone. This material also extends along the lower portion of the trench and extends along the floor of the NP. Because the cone of coarser kimberlite is restricted to the South Crater, it is not thought that additional vents were active within the complex. Petrographic investigation of this material shows that it is characterized by mineralogically similar juvenile clasts and therefore considered the same phase of kimberlite.
The youngest kimberlite units were related to the early, most explosive volcanic activity as medium- to coarsegrained kimberlite extends along the bottom of the entire complex, and is covered by finer grained deposits except for the area around the feeder vent.

The VK unit characterized by common basement clasts is interpreted to represent an earlier kimberlite deposit that does not appear to have been preserved in the South Crater. It is likely that this material represents the remnants of the earliest kimberlite deposited from the initial eruption, and that coevally deposited material in the South Crater was removed later by subsequent eruptive activity.

The mud-rich material that dominates the infill of the NP is thought to have originated from the excavation and incorporation of Lower Colorado and Mannville Group sediments in the south crater, trench and NP areas that was then re-deposited as infill.

\section{Conclusions}

Following the investigation of 47 drill cores from the C29/30 kimberlite it appears that this body is a single volcanic complex that was likely emplaced in a marine setting. C29/30 shares similar evidence for some of the depositional processes described from the 219 kimberlite in the Fort á la Corne field by Pittari et al. (2006). The complex shape of the C29/30 body is interpreted to result from a combination of explosive volcanic activity that formed a crater over the main vent, and an erosive process that transported material away from the vent through poorly to unconsolidated Cretaceous sediments. This erosive process created a deep trough and distal palaeolow into which the transported kimberlite and eroded sediments were deposited. The body infill is dominated by a single phase of kimberlite characterised by variations in structure, texture and the relative abundance of juvenile and xenolithic components that reflect the varied eruption, transport and depositional processes.

\section{References}

Jellicoe, B., Robertshaw, P., Williamson, P. and Murphy, J., 1998 - Summary of Exploration Activities and Results of the Fort a la Corne Diamonds Project, Saskatchewan. In Summary of Investigation 1998, Saskatchewan geological survey, Sask. Energy mines, Misc. Rep. 98-4, 144-157

Napier, S., 2008 - Magnetic Inversion of the C29/30 Kimberlite. Unpublished industry report, Mira Geoscience, 19 pages

Pittari, A., Cas, R.A.F., Lefebvre, N., Webb, K., and Kurszlaukis., 2006 - Facies characteristics and architecture of Body 219, Fort a la Corne, Saskatchewan, Canada; Implications for kimberlitic mass flow processes in a marine setting. Long abstracts of the 2006 Kimberlite Emplacement Workshop, Saskatoon Canada. 